\title{
THE POLITICAL ECONOMY OF REGIONALISM IN WORLD TRADE : IS IT COMPATIBLE WITH MULTILATERALISM ?
}

\author{
M. Sait AKMAN* \\ Muzaffer DARTAN**
}

\section{Abstract}

Regional trading arrangements (RTAs) became popular in the last decade while the trade negotiations of the Uruguay Round continued under the multilateral track of GATT. This Article reopens a discussion that has divided both economists and policy makers as to whether the trend towards "regionalism" in world trade helps to move the process of multilateral trade liberalization forward or leads to more protectionist preferential/discriminatory practices, thereby undermining the multilateral approach of GATT. The authors, in this study, assess the fallacious view that equates regional freeing of trade with "4ree trade" itself and advocate a "public choice" approach arguing that whatever the motivations are for the regionalism, they may, on the other hand, give rise to abuse by domestic interest groups for protectionist purposes and therefore endanger the liberalization of the world trading system.

The surge in regional trade arrangements (RTAs) has been a characteristic of trade relations during the 1980 s and 1990s among nations involving economies at all levels of development. It is also apparent that these two constrasting though related approaches, regionalism and multilateralism, are developing simultaneously. As Srinivasan et. al. (1993, p. 53) stated, these two are not mutually exclusive but have coexisted in the trading system for half a century. While the adherence to the multilateral norm of GATT is still relevant in practice, as in the successful completion of

* Lecturer, Marmara University EC Institute.

* Assistant Prof., Marmara University EC Institute.

1 The term regional trade arrangements used in this study covers a wide range of initiatives each possessing the common denominator of discrimination in favour of certain (partner) countries in trade relations: regional trading blocs; common markels; customs unions and free trade areas. Only the last two are expressly mentioned in the official text of GATT. 
the Uruguay Round of multilatera/ trade negotiations and the increasing applications for WTO membership, it is also possible to observe simultaneously that more and more countries take part in regional trading arrangements based on preferential treatment.

The precise impact of regionalism on the multilateral trading system has always been a controversial issue dividing economists and policymakers. More and more people, nowadays, claim that regionalism is a pragmatic approach reducing trade barriers further among like-minded nations and that RTAs serve as building blocs to multilateralism. They claim that it would be easier to liberalize trade among a few players, i.e. a small number of FTAs or CUs, than among more than one hundred countries. According to this simplistic idea, RTAs move in the direction of liberalizing world trade at a regional level in addition to GATT negotiations at the multilateral level. What is more important is that this idea finds more support in both intellectual and bureaucratic circles each day. In fact, there is no direct contradiction between regionalism and the multilateral system as long as both serve the same purpose; that is to further liberalize trade. We do not deny the role of RTAs in this perspective. Nevertheless, this approach involves two fallacies which may render RTAs insufficient.

lehinde

The first relates to ideas. The proponents of regional integration in trade assume a naive view that if free trade is better than protection, any policy in the direction of free trade, be it multilateral or not, is something acceptable. This idea is comprises a regionalist or bilateralist route best represented by Dornbusch (1990 and 1993) and different from the assertion that "liberalisation of world trade will be faster if it is not only discussed under GATT but also coupled with regional arrangements". This latter wiev is an understandable argument considering the difficulties of the multilateral approach. We may simply call this the multilateralism + regionalism route. The former, however, is a dangerous one as it claims that "multilateralism and GATT does not work at all and that alternative initiatives should be encouraged". Nevertheless, both of these ideas ignore the classical Vinerian thesis ${ }^{2}$ that RTAs may divert more trade than they create and become less open to third country suppliers when the domestic sectors encountering an adjustment within the RTA demand more protection against non-members. In this case, they may become more restrictive than liberalizing. When the interests are defined regionally rather than globally, then regionalism may be regarded not as a supplement to, but as an alternative to, multilateralism in GATT. This begins to mitigate the significance of multilateralism for free trade. This is what makes us worry that regional concentration may lead to the disintegration of the world economy into protectionist trade blocs.

$$
\text { happletrmet yumus a hrom }
$$

2 Viner's pioneering study The Customs Union Issue (New York: Carnegie Endowment for International Peace, 1950) has been a tuming point in the theory of economic integration. 


\section{ivimser}

The second fallacy comes from the sanguine thought that any regional integration is at least a partial liberalization of trade and works against protectionist forces. This is partly true, but one has to see the other side of the coin. As Hoekman and Leidy (1992) asserted, "in the context of negotiating RTAs the industry lobbies (domestic interest groups) that block genuine multilateral liberalization frequently are able to control regional liberalization initiatives as well". The national trade barriers may be replaced by regional ones and preserved in RTAs. Though the role of interest groups is substantial in the trade policy determination process most of the literature on RTAs emphasize the outcomes concerning their welfare effects and external implications. The political economy aspect is largely ignored and internal liberalization is regarded as given ${ }^{3}$.

alum

(2)

on $r$ This article discusses the economic rationale and the motives and expectations behind the drift towards regionalism in world trade and then asks whether it constitutes a threat to the multilateral trading system. It then analyses the extent to which the RTA's serve the protectionist aims of various interest groups. However, the starting point will be a general overview of the current situation of regional bloc formation in the world trade.

\section{1) The Extent of Regionalism in World Trade}

Though RTAs distort the non-discriminatory practice embodied in GATT, the latter has granted a special permission for their (i.e. free trade areas or customs unions) establishment so far as they are notified to and approved by GATT. Since the foundation of GATT in 1948 until the end of 1994 (WTO in force) a total of 108 RTAs were notified, almost 40 of them during the 1990s (Hoekman and Kostecki, 1995)4. Today, over a hundred countries in the world are members of at least one RTA. Free trade areas are the most popular form, out-numbering customs unions five-to-one.

The WTO Secretariat in a recent study (WTO, 1996) has identified 88 individual RTAs currently in force (for a full list see Annex 1).

Regional bloc-formation is not something new the world trade. Its history goes back centuries, to when German towns formed the "Hanseatic League", Europe's

3 Of course there are exceptional studies which contemplate the role of various actors in RTAS such as Hoekman and Leidy (1992), Leidy and Hoekman (1993), Bhagwati (1992), de Melo et. al. (1992) and Tumlir (1983) to name but a fow. This approach is a result of the method employed i.e. What is known as public choice analysis. For a good text on it for Irade policy see, Hilman (1989).

4 According to Trebilcock and Howse (1995) over 80 RTA's have officially been notified to GATT under Article XXIV during 1948-1990. 
first common market ${ }^{5}$. A reinvigoration of RTAs in modern trade history happened following the conclusion of Article XXIV of GATT. During the 1950s and 1960s, numerous regional agreements among developed and/or developing countries emerged (Levy, 1994) (see Figure 1).

\section{Europe}

This was most prominently the case in Europe following the establishment of the ECSC in 1951, the creation of the EEC in 1957 and of the EFTA in 1958. The European Union (EU), enormously distinguished in scope and objectives, even today, stands out as the sole RTA with a fully fledged common market with supranational authorities. The EU (then the EC) was based on a customs union (Treaty of Rome, Article 9) with limited supranational powers. Since then, not only has its membership increased from six to fifteen states, but it has become an economic union with most members adopting a similar economic philosophy. If the current plans come to fruition, this integration process will become further advanced, turning it into an economic and monetary union, perhaps by the end of the century.

The 1980s and 1990s witnessed a resurgence of interest in the European Un. ion in the direction of "regionalism", bringing about an essential aspect of its trade policy, namely, preferential trade relations. The EU (the EC until 1992) has negotiated a series of RTAs with non-member countries under a "hub-and-spoke" approach ${ }^{6}$. Agreements establishing free trade areas (known as "Europe" agreements) with most of the countries in Central and Eastern Europe and a European Economic Area (EEA) with EFTA states are just a few?.

5 The conditions under which trade was carried on made it necessary for the merchants to concert means of securing themselves from oppression and violence... Of the many leagues formed (in this way), the greatest and longest-lived was... known as the Hanseatic League. (It) maintained strongly fortified posts as far east as Novogrod and as far north as Bergen". (Condliffe, The Commerce of Nations, 1951, pp. 42-43).

6 In a "hub-and-spoke" structure there are "spoke" countries (i.e. the associales) each attempting to become the members of a large "hub" (the European Union) at the centre (Henning et. al. 1994, pp. 94-96). EFTA, another hub, has fallen off rapidly after EEA Agreement and accession of some of its members into the EU, leaving the latter as the sole hub in Europe. In this structure, the spokes are not necessarily connected with each other by RTAs. Figure 2 illustrates the current relationship in Europe. For more on "hub-and-spoke" structure see, Hoekman and Kostecki, 1995 and Wonnacott, 1991.

7 The EEA, today consists of only the EU, lceland and Norway after the accession of former EFTA countries namely Austria, Finland and Sweden to the EU. In Switzerland, the electorate rejected the EEA in a referendum daled 6 December 1992. Liechtenstein participales as an observer country. For more details on EEA see, Wijkman in Henning et. al. (1994). 
Figure 1. The network of "reglonalism" in world trade (1996) $)^{1,2}$

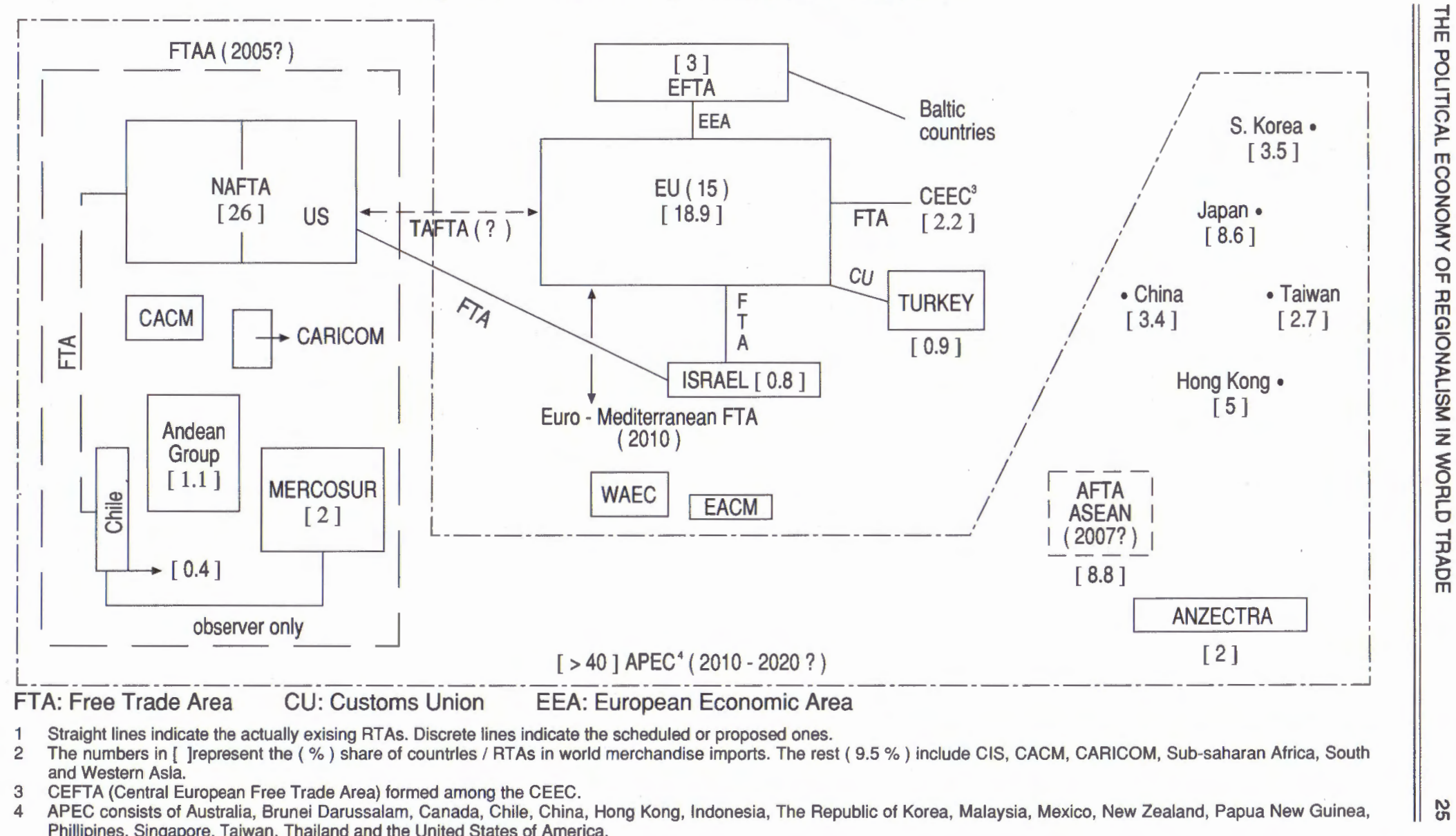


During the second half of the 1980s, the EU's relationship with Central and Eastern Europe changed dramatically. The collapse of socialism led to the removal of the barriers that once separated the economies of the Continent. As the Soviet Union eventually disintegrated and German reunification was achieved, so the EU had to deal with the new states. The EU (then the EC) has negotiated association agreements of the same type (the Europe Agreements) with Czechoslovakia, Poland and Hungary in 1992 and with Romania, Bulgaria and the Czech and Slovak Republics separately in 1993. The Agreements that were signed in 1992 and 1993 operated on an interim basis until their ratification in 1994 and 1995. In accordance with these agreements, most industrial products originating from these countries enter the EU market free of tariffs and quantitative restrictions ${ }^{8}$. Subsequent to the Europe agreements, the trade between the EU and the CEEC grew but the share of these countries in the total trade of the EU is still minor (see Table 1). The EU has also finalised an agreement establishing a European Economic Area with the EFTA, a bloc initially established as a rival to the EC. It included over 400 provisions and just like the Europe agreements intended a full economic integration between the two blocs. The share of the EFTA countries has always been significant in extra-EU trade since 1960. As Table 1 indicates, EFTA represented over one-fifth of the total Community exports until the 1990s and almost a quarter in the early 1990s. Its share in total imports of the EU rose from 15 percent in 1960 up to 23 percent today. Traditionally the EFTA countries have been the closest in the external relations of the EU members. Following the accession of Austria, Finland and Sweden, only Norway, Iceland and Liechtenstein remain as the EEA countries ${ }^{9}$. The EU has finalised the customs union with Turkey, whose accession is on the agenda ${ }^{10}$.

This complex web of regional arrangements is complemented by reciprocal links between EFTA states, Eastern European and Mediterranean countries (see Figure 2). The preferential scheme of the EU covers association agreements with the neighboring Mediterranean countries (Maghreb and Mashreq as well as Cyprus and Malta) and the ACP countries under the Lome Convention which are granted

8 The agreements include several issues in addition to trade provisions. They include measures concerning the free movement of services, workers and capital and economic and monelary co-operation, thus extending them much beyond the traditional free trade areas inlo deeper integration. Aclually, in the European Council meeting in Essen in 1994, the EU decided on a strategy for the eventual membership of these countries. Nevertheless, the timetable is still not clear.

9 Switzerland has refused to take in the EEA after a negative vole in a referandum in 1992.

10 The cusloms union entered into effect as of January 1, 1996 based on the Decision of the Association Council 1/95 daled March 6, 1995. This union had been envisaged in accordance with Article 2 of the Ankara Agreement (1963), establishing an association link beween Turkey and the then EEC. 
Table 1. The share of "spoke" and "preferential" countries in total merchandise trade of EU-12, 1960-1994

EFTA

\begin{tabular}{llllllll} 
& 1960 & 1970 & 1975 & 1985 & 1990 & 1992 & $1994^{2}$ \\
\cline { 2 - 8 } & 21.4 & 25.0 & 22.2 & 22.1 & 26.2 & 24.6 & 22.0
\end{tabular}

$\operatorname{CEEC}(6)^{b}$

\begin{tabular}{rrrrrrrr} 
imp. & 15.0 & 17.4 & 15.6 & 20.1 & 23.3 & 22.6 & 22.4 \\
\hline exp. & 2.7 & 4.3 & 5.5 & 2.7 & 3.1 & 4.9 & 6.8
\end{tabular}

Mediterranean

Basin

ACP

Total share

of spokes in

\begin{tabular}{rrrrrrrr} 
imp. & $2.4^{\circ}$ & 3.6 & 2.9 & 2.8 & 2.6 & 3.7 & 4.7 \\
\hline exp. & 12.6 & 10.2 & 14.0 & 11.5 & 10.7 & 10.3 & 10.3
\end{tabular}

extra EC-12 trade

\begin{tabular}{llllllll} 
imp. & 6.4 & 9.0 & 7.5 & 10.7 & 9.0 & 8.3 & 8.0 \\
\hline exp. & 9.4 & 7.5 & 7.3 & 5.1 & 3.8 & 3.9 & 2.7
\end{tabular}

\begin{tabular}{lrrrrrrr} 
imp. & 9.6 & 8.8 & 7.3 & 7.5 & 4.3 & 3.7 & 3.4 \\
\hline exp. & 46.1 & 47.0 & 49.0 & 41.4 & 43.8 & 43.7 & 41.8 \\
imp. & 33.4 & 38.8 & 33.3 & 41.1 & 39.8 & 38.3 & 38.5 \\
\hline
\end{tabular}

Source: Calculated based on the data in Eurostat $(1994 ; 1996)$

a January - August

b includes countries that have Europe Agreements with EU, namely; Poland, Czech Republic, Hungary, Slovakja, Romania and Bulgaria 
Figure 2. The network of hub-and-spoke agreements in Europe.

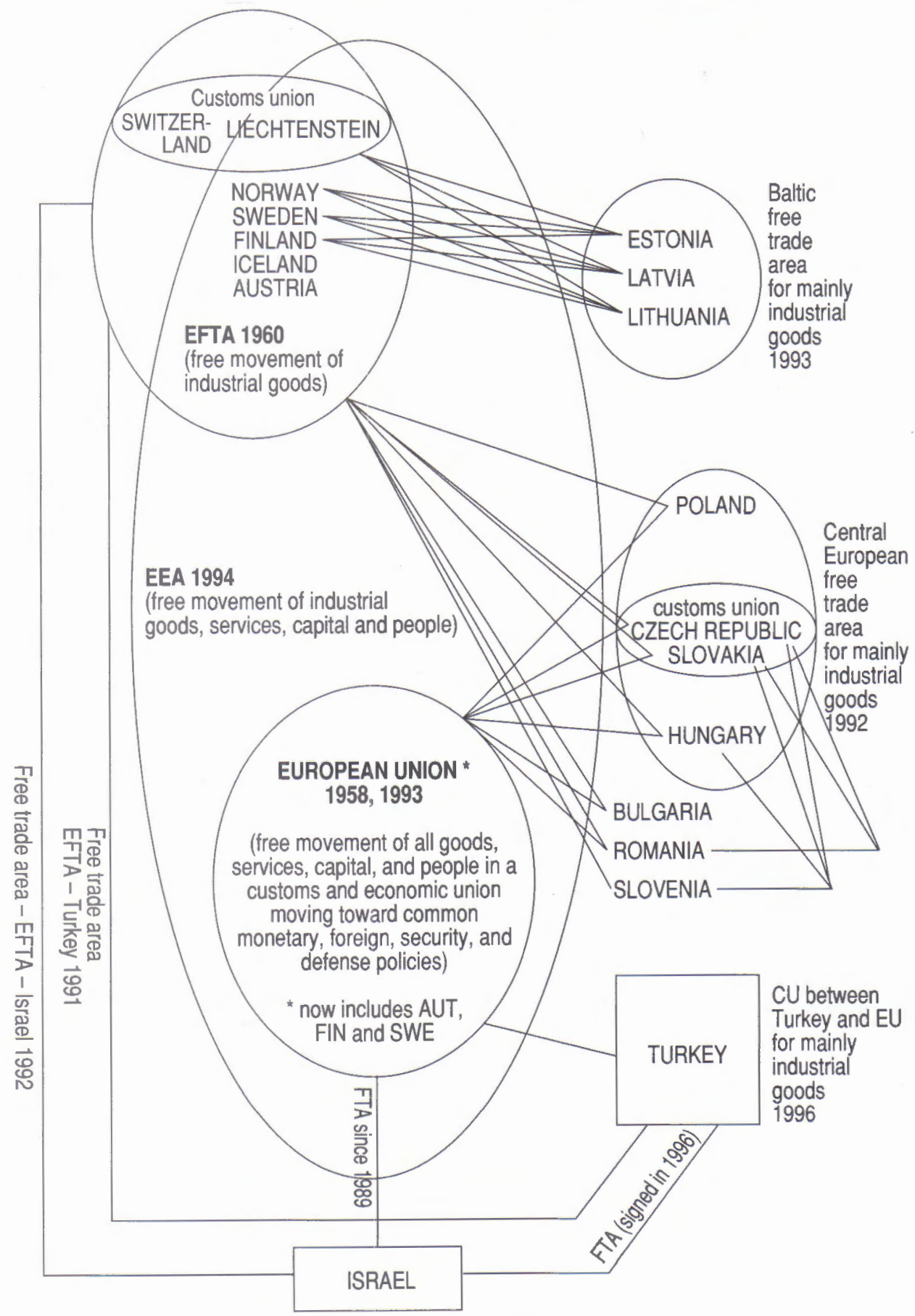

Connecting straight lines indicate the existence of RTAs ratified or applied between the countries / EU in Europe. There are seperate co-operation agreements between the EC and 3 Baltic States. 
privileged access for certain of their products to the European market". Though the share of the Mediterranean countries in the total merchandise trade of the EU has been steady at around 10 percent, the significance of the ACP countries diminished from almost 10 percent in 1960 to 3-4 percent in 1990s although the EU continues to have closer links with them. In 1995, a Euro-Mediterranean Partnership was established in Barcelona where the EU decided to form, by the year 2010, a free trade zone with the countries in the region in which manufactured products will circulate freely and the trade in agricultural products will be gradually liberalised.

The "spoke" (those with which the EU has a kind of RTA) and "preferential" countries constitute 38.5 percent of total imports of the EU in 1994. This amount was 33.4 percent in 1960 and over 40 percent in 1985. They, in return, represent over 40 percent of the EU export markets, while it has been higher since 1960. The figures show that RTAs and preferential schemes with these countries have not brought the expected increase in their traditional trade patterns with the EU. This may be explained partly by the fact that these agreements still contain protectionist clauses especially in sectors that both sides deem to be sensitive for their domestic markets. Secondly, it is to be appreciated that, the trade with the rest of the world is being liberalised under GATT at the same time.

\section{America}

On the other side of the Atlantic, in Americas, the Free Trade Area Agreement (1988) between Canada and the United States (CUSFTA) was tranformed into a North American Free Trade Area (NAFTA) with the inclusion of Mexico ${ }^{12}$.

The NAFTA entered into force on 1 January 1994 and improved and expanded its forerunner, CUSFTA. The main aim is to have a more secure access for the goods and services produced in the three member countries. Despite its name, in many areas it goes well beyond a simple free trade area and regulates new issues such as investment, environment, labor adjustment and movement of professions. It is in many respects some way short of being a common market as it does not provide freedom of movement for all factors and lacks common policies, and is not even a customs union because of the lack of a common external tariff, but is an allembracing free trade pact. NAFTA did not incorporate provisions for supranational in-

11 Note that these preferential agreements are not regarded as an RTA within the context of this study but included in Table 1 because they contain a discriminatory character.

12 This historic trade accord was signed on 17 December 1992 and passed the US Congress in November 1993. There is a growing literature on NAFTA. For a good analysis of NAFTA Agreement see Hufbauer and Schott (1992 and 1993), Lustig, Bosworth and Lawrence (1992) and Grinspun and Cameron (1994). 
stitutions. Because one of Mexico's and Canada's chief concerns was that they should not concede sovereignty to the US, the hegemonic power in the region, many issues pertaining to economic matters were left to be resolved independently by the parties. Therefore, institutionalisation on the EU model with its surrender of sovereignty was avoided. The scale of NAFTA is enormous. It represents a market of over 360 million people with an annual GNP in excess of \$6 trillion (Bello and Holmer, 1993; p. 591). NAFTA proposes the elimination of all tariffs and most of the nontariff barriers on trade among the three members within a period of 10 years (up to 15 years for import-sensitive products). It includes agricultural products in its liberalisation scheme as well. It also stipulates the abolition of all bariers to trade in textile and clothing, a sector traditionally protected in many comparable RTAs. Mexico, as an important supplier country, is anticipated to have an advantage from it vis-a-vis third countries in the US and Canadian markets.

It is intended to remove the barriers to the free movement of capital but not of labour due to Mexico's vast population and small per capita income. Trade between the three partners is extensive. Indeed, trade between the US and Canada generates the world's largest bilateral trade flow (Proff, 1993, p. 279). Traditionally the US is the major market for the exports of both Canada and Mexico.

Table 2. The top three trading partners of NAFTA countries, 1990 (\%)

\begin{tabular}{|rrrrrrr|}
\hline & \multicolumn{2}{c}{ Export } & \multicolumn{3}{c|}{ Import } \\
\hline & Partner & US\$ Bil. & $\%$ & Partner & US\$ Bil. & $\%$ \\
\hline \multirow{2}{*}{ Canada } & US & 95.4 & 72 & US & 75.3 & 62 \\
& Japan & 7.1 & 5 & Japan & 8.2 & 7 \\
& UK & 2.9 & 2 & UK & 4.1 & 3 \\
\hline \multirow{2}{*}{ Mexico } & US & 21.9 & 81 & US & 23.1 & 80 \\
& Japan & 1.6 & 6 & Japan & 1.7 & 6 \\
& Spain & 1.1 & 4 & Spain & 1.5 & 5 \\
\hline \multirow{2}{*}{ US } & Canada & 83.0 & 21 & Canada & 93.8 & 18 \\
& Japan & 48.6 & 12 & Japan & 93.1 & 18 \\
& Mexico & 28.4 & 7 & Mexico & 30.8 & 6 \\
\hline
\end{tabular}

Source : Directory of Trade Statistics Yearbook, 1991. 
As Table 2 indicates, even before the establishment of NAFTA, in 1990, 72 and 81 percent of Canadian and Mexican exports were directed to the US market respectively and they together constituted an export market of 28 percent for the US products. Almost a quarter of total US imports originated from these partner countries. Nevertheless, trade between Canada and Mexico is very small in comparison. In 1995, the total shares of these two countries in the US imports and exports rose to 33.5 and 29.5 percent. The figures reveal that the free trade area induced an increase in the shares of the partner countries in the US markets. The same is true, though with lesser extent, for the US exports' share in the partner country markets.

The US also has a free trade agreement with Israel which entered into force in 1985 and eliminated tariffs and non-tariff barriers in trade until 1995. However, nontariff measures on many agricultural goods are still in operation. The main objective between these two remote partners is, no doubt, political.

RTAs also became fashionable among Latin American countries during the last two decades. Economic integration has been perceived in the region as a means of economic development and of reducing dependence on the developed countries. When the initial attempt at integration (LAFTA) broadly failed, the whole region saw a massive increase in protectionism. By the late 1980s, however, a new mode swept the region as a new wave of integration agreements became popular. In 1980, ALA$\mathrm{DI}^{13}$ replaced LAFTA taking some of its features but furthering liberalisation with the ultimate aim of providing a common market in the region. The already existing Central American Common Market (CACM), Andean Group and Caribbean Common Market (CARICOM) underwent renegotiations leading eventually to a growth in trade between the participants.

MERCOSUR (Mercado Commun del Sur) is another RTA established by Brazil, Argentina, Uruguay and Paraguay in $1991^{14}$. Its main aim is to establish a common market with free movement of goods, services and factors of production as well as the co-ordination of the macroeconomic and sectoral policies. It is, however, far from being a common market and this does not seem to emerge in the short-run, but what comes out is a fully functioning customs union. The tariffs were eliminated in ac-

13 ALADI (Association Latino Americana de Inlegracion) is the Spanish acronym of LAlA; Latin American Integration Association.

14 It was established by the Treaty of Asuncion on March 26, 1991 and incorporated into the ALADI framework. The reason for incorporation into an existing RTA was to avoid the procudure under Article XXIV of GATT. The origin of MERCOSUR goes back to the "Declaration of Buenos Aires" signed between Brazil and Argentina in 1986 for a mutual integration process through several sectoral arrangements. The creation of a Common Market was declared as the objective between these two countries in 1990. Paraguay and Uruguay were later participated as they had the fear of being left out of this huge market.

For a simple summary of the Treaty see O'Keefe (1994). 
cordance with a timetable between 1991 and 1995, though there are still some products in the exemption lists. MERCOSUR constitutes a market of some 200 million people and a GDP of almost \$1 trillion, ranking it as the third largest such RTA behind the EU and NAFTA. The average growth rate of trade among the MERCOSUR members had been 27 percent in the first half of the 1990s whereas its trade with the rest of the world increased only by 7.5 percent during the same period. The intraregional trade is almost 20 percent (Hufbauer and Schott, 1994; pp. 12, 106-113).

Chile, after a long period of isolation, engages in MERCOSUR as an observer and is soon likely to be affliated with NAFTA as a member ${ }^{15}$. Moreover, the US administration has declared its willingness to extend NAFTA to other countries in the region and to create a "Free Trade Area of the Americas" (FTAA) "trom Alaska to Tierra del Fuego" by $2005^{16}$. Should the plan succeed, the FTAA will be a market consisting of 850 million people with a considerable trade volume. The FTAA will be created by the merger of five already existing sub-RTAs, namely; NAFTA, CARICOM, MERCOSUR, CACM and the Andean Pact and Chile.

\section{Asia}

In Asia, RTAs have hitherto not been as attractive as in Europe and in the Americas. The only notable development was the decision in 1992 to launch a free trade area, by 2007, between ASEAN members (AFTA) aiming in 15 years to reduce most tariff barriers (Young, 1993). Nevertheless, as it is often the case with RTAs of this nature, there are two significant exceptions; trade in agriculture and services. Since its establishment in 1967 until 1992, ASEAN was largely motivated by political factors rather than economic ones and little was done to enhance economic integration between the members. Some measures were introduced nevertheless, concentraling on trade liberalisation and industrial co-operation. By 1989, agreement had been reached on tariff reductions for more than 18,00 items, but their impact was limited accounting for less than 5 percent of intra-ASEAN trade. As Panagariya (1994) stated, what encouraged the regional initiative in ASEAN were the negotiations for the NAFTA and for Single European Market by 1992 in EU.

In 1990, intra-ASEAN trade comprised only 17 percent of total ASEAN foreign trade compared to 60 percent of intra-EC and 30 percent of intra-North American

15 Chile already signed a free trade agreement with Mexico in 1991. In 1994, H. Munoz, the Chilean Ambassador to OAS said that Chile is ready to join the NAFTA (International Trade Reporter Jan. 26, 1994).

16 In the Summit of the Americas in Miami in 1994, the Clinton Administration (Democrat) upheld the idea of creating a Western Hemispheric free trade area. Earlier, the Bush Administration (Republican) had conceived the same plan. 
trade (see, Table 3). It is obvious that ASEAN countries generally find it more attractive to export to other regions, mainly to European and US markets, than to trade locally. Excluding Singapore, only 5 percent of ASEAN trade takes place between ASEAN members, and of this, less than 5 percent benefits from any kind of preferential access ${ }^{17}$.

\section{Inter-regional}

RTAs initiatives have a dimension of inter-regionalism as demonstrated by the Asia-Pacific economic region (APEC) to establish a free trade area by 2020 among countries with diverse economic development levels (such as US and Japan on the one side and the Philippines and Papua New Guinea on the other) in Asia and the Americas. Even the possibility of forming a Transatlantic free trade area (TAFTA) was discussed by President Clinton and Prime Minister Major and also suggested by Kinkel, the German foreign minister although it seems unlikely to get anywhere for the foreseeable future ${ }^{18}$.

The trend in regionalism has several repercussions on the flow and liberalisation of world trade. The following observations are worth noting:

First, as Table 3 reveals, the removal of intra-regional barriers to trade through RTAs brought an overall increase in regional trade. The increase, however, is mainly accounted for by the development of the EC. While the intra-EC trade formed only 40 percent of the total trade of the European Community in 1960, this amount reached 60 percent in 1990. A similar rise is also evident in the case of MERCOSUR. The rise of intra-trade in the first half of the 1990s had been of particular importance to the manufacturing sector (19 percent in 1995) although it was only 9 percent in 1990. It is even more significant for the smaller members, i.e. Paraguay and Uruguay.

According to a study by Borrmann and Kopmann (1994), almost half of the world merchandise exports ( 45 percent) went to the partner countries in the regional groupings in 1992, and the intra-regional exports in Western Europe (that is the aggregate of intra-EC, intra-EFTA and EC-EFTA) constituted nearly one third (32.5 percent) of the world merchandise exports.

17 Several recent studies are available on trade in ASEAN. Of these, Panagariya (1994) explains cogently why a free trade area is not leasible in the region. Saxonhouse in de Melo et. al. (1992), takes an opposite view on the potential for integration in this region. For more on the developments in ASEAN see also, Dobbs and Higginson (1995), Kodama (1996) and Young (1993).

18 See, 'Warning on EU-US free trade area', Financial Times, 24 April 1995 and 'Priorities in world trade', Financial Times, 28 April 1995. 
Table 3. The share of intra-regional trade in total trade, by region, $1960-1990(\%)^{*}$

\begin{tabular}{|c|c|c|c|c|c|c|c|c|c|c|}
\hline \multirow[b]{2}{*}{ Year } & \multicolumn{2}{|c|}{ Western Europe } & \multirow[b]{2}{*}{ NAFTA ${ }^{b}$} & \multicolumn{2}{|c|}{ Asia } & \multicolumn{2}{|c|}{ Africa } & \multicolumn{3}{|c|}{ Latin America } \\
\hline & EC-12 & EFTA & & ASEAN & ANZECTRA $^{c}$ & $\mathrm{EACM}^{\mathrm{d}}$ & WAEC & $\mathrm{CACM}^{+}$ & MERCOSUR & $\begin{array}{l}\text { Andean } \\
\text { Group }\end{array}$ \\
\hline 1960 & 40 & 11 & 30 & 27 & 5 & 1 & 2 & 7 & na & 1 \\
\hline 1970 & 53 & 17 & 35 & 17 & 6 & 16 & 9 & 26 & 9 & 2 \\
\hline 1980 & 56 & 14 & 27 & 18 & 6 & 6 & 7 & 25 & 12 & 4 \\
\hline 1985 & 54 & 14 & 33 & 19 & 7 & 5 & 7 & 15 & 6 & 3 \\
\hline 1990 & 60 & 14 & 30 & 17 & 7 & 4 & $10^{\mathrm{h}}$ & 12 & 9 & $4^{\prime}$ \\
\hline
\end{tabular}

Source: Srinivasan et. al. (1993), European Commission (1993) and UNCTAD (1990)
a The figures are approximated
b excluding Mexico
c Australia-New Zealand Closer Economic Relations Trade Agreement
d includes Tanzania, Kenya and Uganda
e includes Ivory Coast, Mali, Mauritania, Niger, Senegal, Benin and Upper Volta (Burkina Faso)
$f$ includes Costa Rica, El Salvador, Guetarnala, Honduras and Nicaragua
$\mathrm{g}$ includes Bolivia, Colombia, Ecuador, Peru and Venezuela
h 1988
i 1989 
The share of intra-regional trade has not changed significantly for other RTAs. The intra-North American trade, for example, has been stagnant around 30 percent since 1960. The same has been true for the EFTA countries during the three decades. The intra-ASEAN trade reduced by 38 percent in the same period. The share of intra-regional trade is still remarkably small in the Andean Group, EACM, WAEC, CACM and ANZECTRA. This is not a surprising result if we consider that these RTAs have not been ambitious enough in lowering trade barriers.

When the RTAs were first initiated, the intra-regional trade expanded rapidly followed by a slowdown in the later periods. This is quite clear for regional groupings among the developing countries such as EACM, WAEC, CACM. In other words the initial trade diversion effects slowed down and trade flows began to turn into more traditional trade patterns.

A similar initial increase in the share of the CEEC countries (from 4.9 to 6.8 percent in two years) subsequent to the reduction in trade barriers under the Europe Agreements is apparent. They have been the country group with which the EU had the highest rate of growth in both imports and exports (see Table 4a) although the case of the EEA was comparably modest.

NAFTA had an affirmative effect on Mexican exports into the US market. As Table $4 \mathrm{~b}$ suggests Mexico has been one of the countries whose exports rose fastest in 1994 and 1995 although the same can not be said for the US exports into the Mexican market in 1995 due to the sharp recession related to the Peso crisis in the latter's economy.

Secondly, the EU is a large market and a sharp rise in intra-regional trade is expected. The completion of the Internal Market with the elimination of existing technical, administrative and fiscal barriers provided a considerable liberalisation of the market for the member countries ${ }^{18}$. NAFTA has strenghtened regional trade in North America and caused a trade and investment diversion. The share of EC and East Asia decreased slightly. Nevertheless, all members had been the traditional trading partners for each other in the pre-NAFTA era. In Asia, on the other hand the RTA does not seem to be feasible. Considering that the regional market is small for ASEAN, it is unlikely to have a substantial free trade area. No RTA in this part of the world will be effective without an active involvement of Japan as a leading trader. As the interests of most countries in the region are strongly linked to exports to Europe and North America the integration was global rather than regional in Asia. None of the RTAs, other than EU and NAFTA, seem to present a large enough market to be inward-looking and they need to be open to the outside. Most RTAs in the developing

19 This does not necessarily mean that the market is totally liberated from all intra barriers and free trade entirely prevails. It can only be said that it is largely free. 
Table 4a. Merchandise trade growth of European Union (15) by trading partner, 1993-1995 $(1993=100)$

\begin{tabular}{llll}
\hline & & 1994 & 1995 \\
\hline \multirow{2}{*}{ CEEC (6) } & $\exp ^{\mathrm{a}}$ & 120 & 147 \\
& imp $^{\mathrm{b}}$ & 129 & 160 \\
\hline \multirow{2}{*}{ EEA (3) } & $\exp$ & 111 & 120 \\
& imp & 110 & 116 \\
\hline \multirow{2}{*}{ United States } & $\exp$ & 112 & 110 \\
& imp & 110 & 114 \\
\hline \multirow{2}{*}{ Japan } & $\exp$ & 118 & 133 \\
& imp & 103 & 104 \\
\hline
\end{tabular}

Source: EUROSTAT (1996

Table 4b. Merchandise trade growth of United States by trading partner, 1993-1995 $\quad(1993=100)$

\begin{tabular}{lccc}
\hline & & 1994 & 1995 \\
\hline \multirow{2}{*}{ Canada } & exp & 114 & 126 \\
& imp & 116 & 131 \\
\hline \multirow{2}{*}{ Mexico } & $\exp$ & 122 & 111 \\
& imp & 124 & 154 \\
\hline \multirow{2}{*}{ Latin America } & $\exp$ & 118 & 123 \\
& imp & 118 & 139 \\
\hline \multirow{2}{*}{ EU (15) } & $\exp$ & 106 & 122 \\
& imp & 113 & 125 \\
\hline \multirow{2}{*}{ Asia } & $\exp$ & 112 & 137 \\
& imp & 114 & 126 \\
\hline \multirow{2}{*}{ Japan } & $\exp$ & 111 & 134 \\
& imp & 111 & 115 \\
\hline \multirow{2}{*}{ China } & $\exp$ & 106 & 134 \\
& imp & 123 & 144 \\
\hline \multirow{2}{*}{ CEEC and CIS } & $\exp$ & 87 & 93 \\
\hline \multirow{2}{*}{ Middle East } & imp & 165 & 199 \\
\hline
\end{tabular}

Source: WTO (1996)

\footnotetext{
a exports to

b imports from

c including Switzerland
} 
world anticipate being a part of a larger one. FTAA is a potential one for those in Latin America. The current Brazilian exports to the US represent a higher value than a total of exports to MERCOSUR partners and other RTAs in the region. The same is valid for CEEC countries as their association agreements with the EU overshadow modest RTAs among themselves like CEFTA.

Finally, the increase in intra-regional trade following the proliferation of RTAs is not surprising as they lead countries to open their markets to the partners' products. The alleged liberalisation of the world trade through RTAs, however, does not seem to add a considerable increase in the growth rate of world merchandise trade. The average growth of world trade during the periods of 1950-1963 and 1963-1973, in which the liberalisation was mainly within the multilateral GATT context, was almost 8 percent and 9 percent respectively. It fell to 4 percent during 1973-1990 and to 6 percent during 1990-1995, in which periods regionalism was the most apparent form of trade liberalisation. It is clear that most RTAs do contain several exceptions and protectionist clauses that mitigate the potential of full liberalisation.

\section{The Admissibility of Regional Trading Arrangements : The Economic Rationale}

In a fully competitive world economy where no market imperfections existed, free trade would provide best policy presenting Pareto-optimal allocation of resources ${ }^{20}$. If, however, it is not possible to attain free trade among so many countries one may ask why a sub-set of these countries should not achieve it by instituting an RTA i.e. a customs union or a free trade area between themselves. Further why should some of the countries be precluded from achieving free trade among themselves, if free trade is something worthwhile. Sometimes it may be more difficult to reach free trade for all and an RTA instead provides freer trade which is better than none.

Nevertheless, such a way of thinking brings us inevitably to an assessment of the Vinerian theory ${ }^{21}$. An RTA represents "freer trade" only to the extent that it results in overall trade creation; that is, the production of some goods shifts from a less ef-

20 GATT (1947) was solely established for this purpose. In its preamble it emhasized the desire of the contracting parties for the "... substantial reduction. of tariffs and other barriers to trade and to the elimination of discriminatory treatment in international commerce" (italics added).

21 When Viner (1950) introduced his original distinction between "trade creation" and "trade diversion" he specificaally studied the "customs unions". His main contribution to the theory, as Bhagwati (1991) wrote was "to destroy the common fallacy that a preferential move loward total free trade was necessarily welfare improving". This is not to say, however, that earlier classical economists did not deal with the trade restricting characteristics of RTA's. Adam Smith, Ricardo and McCulloch each denounced the Methuen Treaty belween Porlugal and Great Britain on the grounds of its trade diverting effects (Robson, 1987, p. 5). 
ficient member country in the RTA to a more efficient one. It does, on the other hand, represent "rectricted trade" in cases where trade diversion is the outcome (McMillan, 1993). So the RTA has two components, one being conducive to free trade and the other being hostile ${ }^{22}$. It is the apparently beneficial aspect that generally generates sympathy for RTAs among free traders. Kemp and Wan (1976) have demonstrated that if the common external tariff is adjusted low enough to prevent trade diversion, the members of a customs union can always ensure a gain (Krugman, 1991 p. 11). The proposition put forward by Kemp and Wan shows that an RTA may be welfare increasing under certain conditions :

22 Let us assume that countries $A$ and $B$ decided to establish a customs union (CU) between themselves leaving $\mathrm{C}$ outside and suppose $\mathrm{x}$ is a product that country $\mathrm{A}$ produced under tariff protection belore the CU. If $\mathrm{B}$, the partner country, is the least-cost producer of the said product, after the abolition of tariffs A will increase its imports from B. Thus, the removal of tariffs for B will create trade and would work similarly for the removal of tariffs under multilateral trade negotiations without discrimination.

The areas $a+b+c+d$ in Figure $3 a$ show the net welfare gains for consumers. The difficulty with RTAs starts when there is a more efficient country than B (the partner country) outside the union, let us say $C$, in producing $y(B$ is able to outcompele $C$ in $A$ 's market when $C$ is subject to a tariff $t c$ but $B$ is not). In Figure 1b, area e denoles what is paid by consumers in $A$ to the less efficient producers in the partner country $B$ (trade diversion). The larger the area $\theta-d$, the higher will be the welfare loss from the CU.

\section{FIGURE 3a Welfare Effects of Trade Creation}

PP' is the partner-country supply curve. Tariff removal cuts domestic price from OT to OP, expands imports to M'N' and raises weltare by areas $\mathbf{b}+\mathbf{d}$

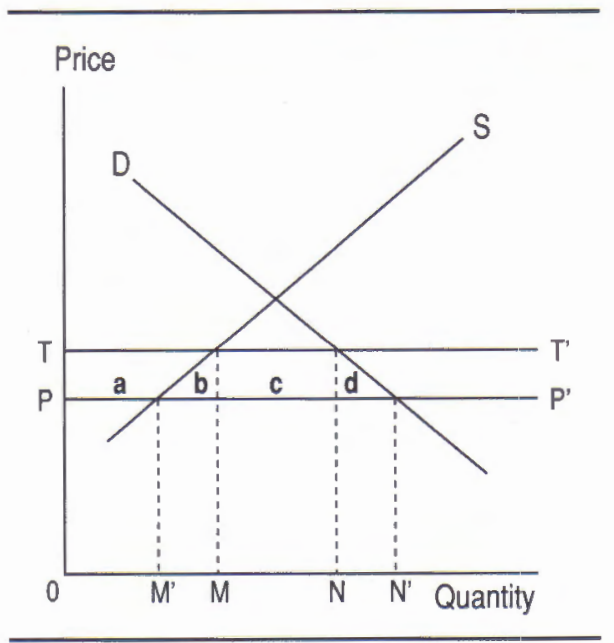

FIGURE 3b Welfare Effects of Trade Diversion

$\mathrm{P}_{\mathrm{B}}$ indicates pretariff supply price in partner country. $\mathrm{P}_{\mathrm{C}}$ is the pretariff supply price in rest of the world. Tariff preference lowers internal price from $T_{C}$ to $P_{B}$ Welfare loss occurs if area e exceeds area $\mathbf{d}$.

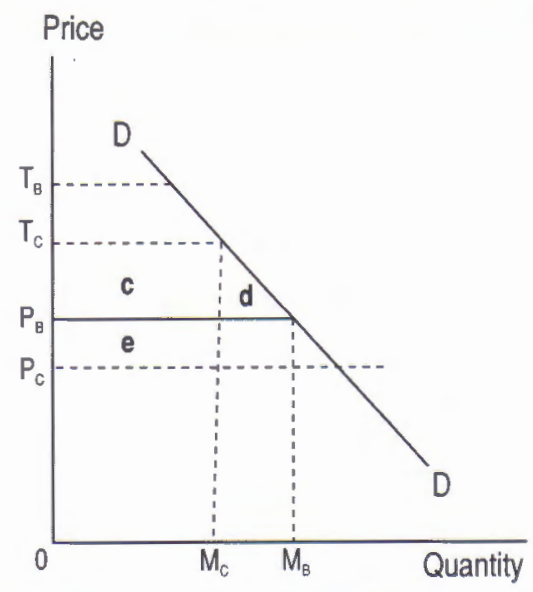


"Let any subset of the countries form a customs union. Then there exists a common tariff vector and a system of lump-sum compensatory payments, involving only members of the union, such that there is an associated tariff-ridden competitive equilibrium in which each individual, whether a member of the union or not, is not worse-off than before the formation of the union." $(1976$, p. 95).

Accordingly, under these assumptions a customs union will not only create trade but will not cause any trade diversion. Therefore it will be possible, with finite sequences of these steps, to reach a single customs union in the world (this is precisely the ideal of universal free trade of the GATT) if at each step a new customs union is created or the existing ones are enlarged and that no individual state is made worse-off (no trade is diverted) ${ }^{23}$. The full integration of trade under a customs union between $n$ countries is not, in theory, different from the customs union of a single country (because each country in itself is a CU) and this may legitimise an exception to the Most Favoured Nation (MFN) obligation in GATT (Bhagwati, 1992 p. 537).

The beneficial aspect of RTAs in respect of free trade was reflected in the GATT text by its draftsmen. Although drafted before much of the economic literature was developed in this area, Article XXIV of GATT appears to be in consistency with what the theoretical prescriptions subsequently proposed.

The US did not like the idea of a preferential system introducing discrimination into the multilateral approach they desired to effect by the GATT. They did not try to prohibit this move either (Dam, 1970 p. 274). In fact, this was a result of the compromise between the US and Europe during the International Trade Organization (ITO) negotiations. As the major European countries were looking for ways to reconstruct their war-torn economies they discussed a Western European Customs Union. A French proposal at the Havana Conference "to increase freedom of trade by encouraging the development of greater economic unity throughhout areas more extensive than those defined by political frontiers" was backed up by other European states and finally included in GATT (Curzon, 1965 p. 260 and Haight, 1972 pp. 39596).

In Article XXIV the draftsmen set forth precise rules that determine the circumstances under which regional arrangements may be permitted. These were essential in guaranteeing RTAs that give the "highest trade creation" and the "lowest trade diversion" possible. 
Two of these deserve mention. First, trade barriers after the integration should not rise on average. Clearly, if the RTA does not induce more restriction on the imports from non-member countries than before, the reduction of imports will be limited. In the case of customs unions, the duties (common external tariff) and other regulations of commerce "shall not on the whole be higher or more restrictive than the general incidence of (those) applicable .... prior to the formation of such a union" (Article XXIV:5(a)). For the free trade areas, the protection level is not to be increased (Article XXIV:5(b)). Although it has an ambiguous wording ${ }^{24}$, it is obvious that this requirement was added to minimize trade diversion. Therefore, any a la Kemp-Wan RTA complying with this requirement is conducive to the expansion of trade on the basis of multilateralism and non-discrimination.

The wording of the relevant provision, however, may not in itseff provide a reduction in trade diversion in all cases. Consider a $\mathrm{CU}$ between $\mathrm{A}$ and $\mathrm{B}$ where the pre-union tariff level of $A$ was higher than that of $B$. Assuming that the trade volume of $A$ is much higher, any arithmetical average to attain the common external tariff will lead to more restriction. It could be argued that the phrase "general incidence" does not require a mathematical average. In presenting its case the EEC used this method arguing that the provisions of this clause allowed any method of calculation (Jackson, 1969, pp. 611-613). Such circumventions are possible for important actors in GATT.

The most important point is that the relevant clause mentions not only the duties but also "other regulations of commerce". Today, the main barriers to trade arise from non-tariff measures. The EC has been one of the most frequent users of antidumping and safeguard weapons and forced many non-member countries to "voluntarily" limit their exports to EC markets. The protectionist implementation of the common commercial policy has served as a factor to divert trade to a significant extent $^{25}$.

Secondly, the draftsmen expected the RTAs to be on balance trade creating. In Article XXIV:8 (a) and (b), they required that, in the formation of a customs union or a free trade area, duties and other restrictive regulations of commerce are eliminated with respect to "substantially all trade" between the member states. The provision is ambiguous and creates a difficulty in the interpretation of what constitutes "substantially all". Is 70 per cent a sufficient amount or should it be at least 97 per cent? Even if the general tendency is to assume 70 per cent as substantial elimination, would it then be possible to consider the RTA in question a compatible one within the context of Article XXIV if trade in products forming the remaining 30 per cent is left

24 This ambiguity in the criteria has been a reason for the high degree of tolerance for most RTAs notified to GATT. For more details see, Dam (1970, chapter 16) and Jackson (1969, chapter 24).

25 Schuknecht (1992) is essentially good in the explanation of protectionism in the EC's trade policy. 
outside the elimination scheme? (Akman, 1991). This was in fact the situation in some RTAs such as EFTA where the elimination of trade barriers in agricultural products was not included ${ }^{26}$.

Besides the sectoral exclusions, almost all RTAs contain provisions involving exceptions and safeguards of various kinds. In addition to those already permitted in Article XXIV:8(a) and $(b)^{27}$, provisions conductive to contingent protection are, no doubt, inevitable parts of an RTA. The most particular examples are the clauses to restrict trade in cases of dumped or sussidized products from the partner countries (similar to Article VI and XVI in GATT) and safeguards in case of a sudden surge of imports threatening or actually causing serious injury to domestic industries (similar to Article XIX in GATT). Frequent resort to these measures, in an abusive way, by the domestic producers and a high degree of tolerance by the domestic authorities of protectionist motives will reduce the potential for trade creation.

Article 115, for example, allows the Commission to authorise a member state in the $\mathrm{EC}$ to take protective measures to limit the importation of products originating in non-member states in cases where the execution of the measures of commercial policy leads to economic difficulties. Quantitative restrictions also deserve attention. The EC, after abolishing tariffs on the textile and clothing products from Turkey in the first stages of the customs union, continued to apply quotas until $1996^{28}$.

Other RTAs contain similar restrictions. For example, the NAFTA will not eliminate duty drawback on Mexican trade until 2001 and does not bring in a regular system to revise these rules (Hufbauer and Schott, 1993). In MERCOSUR, Brazil decided to set quotas for vehicle imports from Argentina due to the pressures from the domestic auto industry.

26 In the GATT report concerning EFTA, the following argument, however, was raised;

"substantially all trade had a qualitative as well as quantitative aspect and that it should not be taken as allowing the exclusion of a major sector of economic activity. For this reason, the percentage of trade covered, even if it were established to be 90 per cent, was not considered to be the only factor to be taken into account."

For more details, see Jackson, ibid. p. 607-609.

27 The Article XXIV:B allows members of an ATA to continue to apply the exceptions already stipulated in GATT. These are; Article XI: which permits the use of export restrictions or prohibitions to prevent the shortage of foodstuff or other products essential to the exporting country (in the case of RTA, the member state concerned) and prohibitions or restriclions of imports and exports for the purposes of the application of standards, regulations for the classification, grading or marketing of commodities, Article XII and consequently Article XVIII: B which allow trade restrictions on imporls to safeguard a country's external financial position and its balance of payments, Article XV which allows the use of exchange control or restrictions in certain situations and Article $\mathrm{XX}$ which approves general exceptions such as those necessary to protect public morals; human, animal or plant life or health, etc.

28 For a concise study on EC-Turkey trade relations see, Balkur in Balkur and Williams eds. (1993) pp. 137-189. 
In other words, national interest may be interpreted as requiring the inclusion of protectionist instruments in regional trade negotiations as well as the multilateral ones under GATT. The higher the level of such protectionist instruments within the RTA (and against the outside), the lower will be the difference between areas $e$ and $d$ (see footnote 22). This may even amount to the case in which the RTA is more trade diverting than trade creating. As Bhagwati (1992) stated "trade creation can degenerate rapidly into trade diversion, when antidumping and VERs are freely used".

\section{The Unbearable Attractiveness of Regionalism}

The following parts examines the political economy of RTAs using a public choice approach. Two propositions may be set to evaluate the effectiveness of regionalism for the liberalisation of world trade. Firstly, it would be unwise to reject the idea that regional integration has played a significant role in furthering the liberalisation of world trade. Nevertheless, it may be proposed that this role is exaggerated to a large extent and those who see regionalism as an efficient route for trade talks sometimes went so far as to propose it as an alternative to multilateralism. The second proposition relates to the intrinsic protectionist tendencies in RTAs disguised by their 'apparently' liberal face. The latter is differs from the classical trade diverging case of RTAs but can only be apprehended by a careful analysis of the domestic policy formulation. We start with the first proposition. The second will be dealt with subsequently.

It is certain that the liberalisation of trade by means of RTAs is different from multilateral trade negotiations under GATT. Nevertheless, more attention has been diverted into the regional initiatives in the last two decades. When the draftsmen of GATT had opened the way to RTAs by providing the legal channel set out above, they were not aware that, after forty years a repor ${ }^{29}$ would be finalised by a committee attended by the then Director-General of GATT concluding that Article XXIV should be revised. According to this report "the rules permitting the customs unions and free trade areas have been distorted and abused. In order to prevent further erosion of the multilateral trading system, they need to be clarified and tightened up." It emphasized that many RTAs including those between the EC and its associates "tall short of the requirements of GATT and that the exceptions and ambiguities permitted have seriously weakened the trade rules". They warned that the trading system might become fragmented. It is, indeed, vital to note that the pragmatic side of the RTAs has always overshadowed the problematic role that they may play i.e. to generate a

29 In 1983, the Director-General of GATT asked seven eminent persons to form an independent group to study the problems facing the international trading system. Their Report "Trade Policies for a Better Future" is generally referred to as the Leutwiler Report named after the Chairman of the group. They have made a series of proposals of action for trade policy matters including regionalism. The Report first appeared in 1985 but was published in 1987. 
friction in world trade among trading blocs and politicize it more. Does this mean that confidence that regionalism will lead to free trade for all was lost? The answer is obviously ' $n o$ ' but the revival of regionalism may not in all cases lead to multilateral free trade as an ultimate goal.

This may be better explained by exploring the reasons for a drift in regionalism, involving a bilateral character, as the preferred route of trade liberalisation ${ }^{30}$. Why is there, today, an interest in the RTAs after so many years of the multilateral, rulebased GATT approach which dominated international trade policy?

The reasons are various:

The first and the most compelling relates to whether multilateralism has been considered as viable by the nations concerned.

In economic theory, the idea that a regime of multilateral free trade was the best approach for liberalisation of trade and increasing economic welfare is widespread. Therefore, RTAs have not been popular among professional economists ${ }^{31}$. The reasons are clear both politically and economically. As Krueger (1990) puts it "free trade can best flourish in an environment of multilateral rules and negotiations". According to Lawrence (1990) the multilateral negotiations give countries a greater ability and incentive to make trade concessions compared to cases in which they are just negotiating with a single country. The latter is a case represented by bilateral (and regional) arrangements. Lawrence is clear in arguing that bilateralism may not provide the best economic results.

"The benefits of multilateralism are similar to the benefits of money over barter. Bilateralism, like barter, requires a double coincidence of wants. However, multilateralism allows a country to obtain a concession from one country by providing a benefit to another. It can increase the number of potentially liberalising deals (pp. 136-137).

From a global economic perspective, regional deals distort the efficient allocation of resources and reduce welfare ${ }^{32}$. At this point one may ask "if multilateralism has such merits why is it coupled with regionalism?" What is it that we understand by

30 Regionalism, of course, is not the only process in trade negotiations. Multilateralism is still the most comprehensive mode. Despite widespread praise for the latter, on the other hand, recent liberalisation of trade involved an increasing number of regional (discriminatory) agreements. This trend is evident in Annex 1. For a detailed study concerning various forms of trade liberalisation see Yarbrough and Yarbrough (1992).

31 See, for example, Krueger (1990); Bhagwati (1991 and 1992); Lal (1993); Aho and Ostry (1990); Schott (1989); Dam (1970) and Baldwin (1987).

32 This is one reason why RTAs are regarded as "second-best" in theory, compared to global free trade. 
and expect from multilateralism. Perhap neoliberals ${ }^{30}$ defined it best. They perceived it as a "decentralized framework for the negotiation and maintenance of mutually advantageous bargains among slates" (Trebilcock and Howse, 1995). Only in this way the did countries co-operate in liberalising trade. GATT was established to serve this purpose. Nevertheless GATT's success may be measured by the extent to which it managed to reduce the information and transaction costs involved in ensuring 'mutually advantageous bargains'. The transaction was costly for large members compared to a system consisting of a small number of like-minded nations. As neoliberal analyses presumed, large number of participants create an inevitable obstacle to $\mathrm{co}$ operation (Kahler, 1993; p. 297).

This has been a problematic issue in GATT as the number of contracting parties increased and most countries started to agree on the practical aspects of regional or bilateral deals, in that it is easier and quicker to have an accord on the negotiating agenda and conclude bargaining in less time than if they are involved in multilateral negotiations. Furthermore, as Baldwin (1987) argued, this also enables them to focus on issues they deem as most crucial and directly relevant to their circumstances. Even the US, the most ardent supporter of multilateralism since early the 1980's, showed an interest in regional deals when the relative decline of its economic power started to be felt ${ }^{34}$. The idea that multilateralism has defects in providing co-operation among a large number of countries due to high transaction costs has been one of the reasons leading some countries to participate in RTAS. However, this idea that "multilateralism does not work" (a regionalist or broadly speaking bilateralist viewpoint) is open to challenge.

Astonishingly it is also possible to come to the same conclusion concerning the popular case of RTAs, this time not because the "multilateral norm of GATT has defects" but because "it was successful". Let us explain. The 1980s and 1990s characterised by neoliberal policies were a period of change. The attempts to cut public spending and the Keynesian welfare state; privatisation and deregulation; tight monetary policies to keep inflation at low levels; increased capital movements facilitated by financial market liberalisation and more importantly the liberalisation of trade by

33 The neo-liberal perspective is best illustrated in Keohane (1984) and Lipson (1984).

34 It is understanable that all countries take part in intemational regimes to foster their private aims. In other words, they continue to abide by the norms and rules of the regimes as long as their national interests are fulfitled. International regimes and organisations, including GATT, provides a public good encouraging some countries to behave as free riders. Soon, some policymakers and economists in the US came to the proposition that due to the incentive for free riding, the small nations contribute a low share of the cost compared to the US and therefore the costwenefit ratio has fallen immensely for the US while there was an increase in the case of Japan, Germany elc. The public choice analysis is useful in understanding the motivations for being a member of smaller regional clubs than larger institutions. Frey (1991) explains well the benefits and costs of joining such international organisations. 
reducing tariffs and some non-tariff barriers as a result of GATT negotiations increased economic interdependence. These caused nation states to loose their ability to control their domestic economies independently. However, to recapture its lost economic sovereignty some countries demonstrated an increasing tendency to form RTAs as they saw them as alternative forums to continue their national stance compared to large multilateral organisations.

Secondly, it could be argued that most countries still possess mercantilist modes of behaviour by looking upon free trade as a zero-sum game. There are two legs to this behaviour at a policy level. One is to restrict imports as much as they can while the other is to expand exports. The first leg cripples after the liberalisation of trade thanks to GATT and neoliberal economic policies pursued after the $1980 \mathrm{~s}^{35}$. This required those countries concerned to rely more on the other leg. In this perspective, regionalists claim that RTAs are quicker ways to force others' markets to be more open and to have improved access to new ones.

Indeed, the US policy in building a trade bloc in North America or in the Americas at some point in the future, rests on this view. Similarly, Argentina and Brazil were aware of the need for larger markets for their export products. The preamble of the Treaty establishing MERCOSUR emphasized the need for the "importance of securing their countries a proper place in the international economy". This statement is an indication of the intention of the signatory states to guarantee export markets for one another.

The same is true for the EU, which would like to have privileged access to the newly emerging markets of CEEC (Europe Agreements) and CIS countries as well as other European markets.

While regionalism became a policy for hubs, the spokes started to exert a similar trend. The fear of being excluded from a trade bloc and to be subjected to the discriminatory trade practices of the hub in the region has been the stimulus to enter into the nearest RTA.

The risk to Canada in staying out of the free trade negotiations in the Americas and loosing her market share by the erosion of the rights she acquired via GATT negotiations was the motivation for Canada to take part in regional schemes (Trebilcock and Howse, 1995 p. 96). The same thing seems true for Chile, the only isolated mar-

35 This is not to say that the idea of protecting trade diminished, but it goes with new non-tariff barriers under new forms. What we claim is that GATT was successful enough to provide a regime to cope with trade barriers for which it was designed. On the other hand it was not ready to fight against new challenges from prolectionist forces and therefore needed to restructure accordingly. Finlayson and Zacher (1983) are particularly good in describing the strength of GATT trade barriers regime and its principles and norms. 
ket-economy country in Americas, when she expressed her intention to become a member of MERCOSUR and NAFTA.

In Europe, considering the similar export product compositions, the CEEC countries signed RTAs with the EU one after another, in order not to loose their market share. Similarly Paraguay and Uruguay feared to be shut out of a common market between two of their largest trading partners forced them to take part in the MERCOSUR process.

We should admit that the integration process is far deeper than a mere trade liberalisation from a bilateral base, such as a free trade area or customs union. Therefore, the dynamic effects of further steps of integration i.e. free movement of capital and labour, co-ordination or unification of exchange rate and monetary poicies supports a more positive approach to RTAs ${ }^{36}$. Preusse (1994), on the other hand, emphasizes a vital distinction between regionalism and regionalisation. The distinction was first referred to by Lorenz (1991) $)^{37}$ as a natural outcome of the development of the integration process which has both vertical and horizontal aspects. That is to say that in the regionalisation process an RTA must be open within and between the regions. Otherwise a closed RTA would not be conducive to multilateral free trade.

There are, of course, other non-economic, political or even cultural factors driving countries to become a member of an RTA. Bhagwati (1991) rightly observes the cases of Turkey and Mexico in their interest for EU and NAFTA respectively:

"Just as Turks since Ataturk ${ }^{38}$ have tried to seek a European identity... the Mexicans clearly seek now an American future rather than one with their southern neighbours...".

While, these factors give us some idea of the expectations of countries from regional trading arrangements, they do not change our proposition that :

36 However, deeper economic integration is feasible if certain conditions are mel. It is not the aim of this study to analyse them but it could be argued that the only successful case so far has been the EU.

37 Regjonalisation, according to Lorenz is an empirically observable concentration of economic activities and regionalism, on the other hand, implies that regional concentration is politically desired and therefore actively pursued. The term RTA in this study reflects the characteristics of both. However, the RTAs, though they may have the intension of regionalisation, may not fulfil the criteria for a successful integration if they are not open enough within themselves and towards outsiders. As Sapir (1993) states "provided RTAs adopl a fairly liberal trade regime, the chances are that they benefit world trade". Whether the EU, as a good example of regionalisation, has a "fairly" liberal trade regime is yet to be seen.

38 Bhagwati starts his observation from the early Republican era but this tendency goes back even to earlier periods when Turks first started to be interested in having deeper relations with Europe. 
RTAs are not more liberalising for world trade compared to a multilateral system of GATT and they may, in certain cases, even hinder the multilateral process.

\section{The RTAs are Liberalising but No More So than GATT}

The liberalisation of trade under the multilateral process might have difficulties concerning the high transaction and information costs. The fundamental advantage of an RTA is its positive effect in mitigating these costs by limiting the number of parties involved in negotiations. The parties will be more eager to participate and accept the rules in such small groupings as their stake will be higher due to less free-riding among members. This is generally the opposite in larger groupings like GATT. However, as the number of countries in an RTA increases with time, which should normally be the case if further liberalisation is to take place, then "the potential for problems would be enormous" as Krueger (1990) rightly posits. Her example is illustrative;

"Consider how the Canadians, who bargained for better access to the American market in some agricultural commodities, might react if the US now bargains with Australia for access to the same market on the same terms. Canadians might feel that they had lost something they had bargained for."

Actually, this is one problem associated with the existing balances within an RTA. If a member acquired trade diversion, it will be reluctant to lose it. This, no doubt, hinders the expansion of liberalisation compared to a multilateral system based on an MFN clause. The latter provides more economic gains from trade liberalisation by permitting greater specialisation.

This brings us to the fact that the RTAs are not more liberalising within themselves and are no less restrictive to outsiders. The following points elucidate this proposition :

First, the agenda of the Uruguay Round of multilateral negotiations has been large including the liberalisation of trade in agricultural products and services while the record of the RTAs in these issues has not been encouraging. Most regional agreements excluded such sectors. Moreover, problems of trade in several areas like agriculture, subsidies, intellectual property and financial services can be better solved multilaterally. Take agriculture for example. The negotiations of the Uruguay Round forced the EU to liberalise, though partly, its notoriously protectionist CAP. It would not even be possible to anticipate the result under a regional agreement to which the EU is a party. The EU's negotiating power would preclude such steps. In fact, the trade in agricultural products is still subject to severe limitations in the RTAs 
of the EU. The customs union with Turkey and the free trade areas with CEEC do not explicitly address free trade in agriculture ${ }^{3}$. In NAFTA, the US and Canada failed to further liberalise farm trade (Hafbauer and Schott, 1993). The parties agreed to keep nontariff barriers in sensitive agricultural goods and phase out the remaining tariffs ovei long periods ( 15 years in US-Mexico trade).

Also, compared to bilateral deals in RTAs, the 'all-or-nothing' approach of the Uruguay Round had two advantages: to offer a greater scope for cross-sector concessions and thereby to promote a rapid pace of liberalisation and to create the greatest amount of trade.

Second, the multilateral liberalisation does not cause the traditional trade and investment diversionary effects of the RTAS. This is an essential point especially for smaller countries outside the region, but has a serious impact on their conventional export markets. The case of the Dominican Republic is a good example. This tiny Caribbean country has been the sixth largest supplier of clothing to US market until 1993. However, by 1994, not long after NAFTA came into being, Mexico, having gained priviledged access to the US market, started to increase its exports by 50 per cent. The annual growth rate of 25 per cent for the clothing exports of the Dominican Republic has diminished markedly to only 1.2 per cent in 1996 (South, May 1997) bringing job losses of 17.000 .

Yeats, the chief economist of the World Bank, had a similar concern for MERCOSUR. According to him, those products having a intra-export growth are mainly transport equipment and electrical and non-electrical machinery for which member countries "have not demonstrated an ability to export competitively elsewhere" ( $F$. Times, 4 February 1997, p. 14).

Third, such regional arrangements may provide a stronger bargaining power to member countries. This as Lal (1993) expressed may, in turn, cause a diversion of its energy from global trade into second-best regional schemes. This is a compelling reason as to why countries are so desirous on RTAs. This is one reason why the EC was unwilling to start multilateral trade negotiations in 1982 (Bhagwati, 1992). Indeed, it is not realistic to assume that a large trading entity like the EU or NAFTA would not have an effect on its member states' terms-of -trade $e^{40}$. This reduces the extra-imports of the RTA. Emerson et. al. (1988) claimed the removal of trade barriers

39 Agricultural trade will be regulated in accordance with the principles of the Common Agricultural Policy. This shows that RTAs in this respect go no further than the deal in the Uruguay Round. Though the tariff levels applied by the EU are comparably low, the prolection is extensive through the price mechanism and subsidies.

40 The literature in economic integration theory deals with this aspect. Mundell (1964), for example, has shown in his study that a reciprocal reduction of trade impediments inside a customs union must worsen the outside world's terms of trade. 
in the internal market of the EC would have a negative repercussion on third country exports to the Community.

The terms-of-trade effect will eventually render the Kemp-Wan approach to be unrealistic.

Fourth, as Hindley and Messerlin (1993) suggested, the RTAs may be used by the new member countries to mitigate the effect of outside competition by imitating or accepting the more protectionist policies of club members. Spain was not an active user of antidumping actions before she joined the EU. After accession, Spanish firms learned well how to resort to such non-tarift barriers. The similar case of Turkey reinforces this proposition. The Customs Union between Turkey and the EU required the former to harmonise her trade legislation with the EU. Until now, the traditional form of trade protection in Turkey has been through tariffs and charges having equivalent effects. The Customs Union has passed dangerous non-tariff weapons into the hands of domestic producers. The antidumping allegations are potential ones. Indeed, the number of antidumping investigations grew rapidly following the Union ${ }^{41}$. Hindley and Messerlin reveals in their study how the antidumping cases initiated by the EU are imitated by Turkey in terms of both products and countries (p. 376).

Finally, almost none of the regional schemes remove all barriers to intra-RTA trade and almost all of them are full of exceptions and exclusions. The RTAs do not eliminate trade restrictions with respect to substantially all the trade. Many RTAs were far from fully liberalising certain sectors. Agricultire is, in this respect, notorious. A number of industrial sectors are assumed to be sensitive and given a special treatment. It must be admitted that most of the RTAs eliminate tariffs and quantitative restrictions (QRs) on a large scale in internal trade in industrial products. However, the tariffs have been replaced by nontariff barriers in the last two decades and most RTAs allow their members to apply them in intra-regional trade as well as externally. They continue to permit 'contingent' protection of domestic markets through 'antidumping actions' and 'safeguard measures' (usually quotas) where imports from the partners were considered injurious. This is especially the case in sectors that are deemed to be sensitive such as textiles and clothing, steel, footwear, electronics and chemicals. Recent 'Europe' agreements between EU and the CEEC, for example, require tariffs and QRs to be phased out within one year but allows the EU to protect its markets from the imports in sectors in which the CEEC's competitiveness is high. These, however, represent the sectors of export significance to these countries (Winters and Wang, 1994). Table 5 points out that almost half of the imports of these countries are under protectionist threats from the EU.

41 In 1995, 11 definitive AD duties were applicable and 38 measures were in force in Turkey. Mexico, after its entry into NAFTA, increased its resort to AD. The number of provisional duties reached to 18 while definitive duties were 3 and price undertakings were 3 , in 1995 (WTO, 1996). 
Table 5. CEEC exports to the EU in 1989 (product composition)

\begin{tabular}{lcccccc}
\hline & Bulgaria & Czechoslovakia & Hungary & Poland & Romania & CEECs \\
\hline Agriculture & 16.3 & 8.0 & 25.3 & 19.9 & 3.8 & 14.7 \\
Footwear, toxtiles and clothing & 11.6 & 12.6 & 17.6 & 11.7 & 19.5 & 14.6 \\
Iron and steol & 10.5 & 12.5 & 4.9 & 5.3 & 5.0 & 7.6 \\
Chemicals & 11.6 & 11.8 & 10.0 & 6.7 & 4.4 & 8.9 \\
Total of above & 50.0 & 44.9 & 57.5 & 46.6 & 32.7 & 45.7 \\
\hline
\end{tabular}

Source : Rollo and Smith (1993)

The benefits of these agreements also diminish due to the restrictive safeguard provisions that allow the EU to curb the exports of these countries when it considers them to be causing 'serious injury' to EU producers or 'serious disturbances which could bring about a deterioration in the economic situation of a region'. Nevertheless, these are vaguely defined phrases open to abuse (Messerlin, 1992).

In NAFTA, on the other hand, similar NTBs continue to exist. In the car industry, for example, tariffs will be eliminated over 10 years. In textiles and clothing, all tariffs and quotas will be phased out in 10 years (Hufbauer and Schott, 1993). This is no faster than the liberalisation in the Textiles and Clothing Agreement of GATT. The same is true for trade in agriculture which is regulated under bilateral agreements and special safeguards in the form of tariff-rate quotas which apply for 10 to 15 years. NAFTA has highly restrictive 'rules of origin' for goods so that they qualify for preferential treatment. Accordingly, they must include a specified percentage of North American content. These figures are as high as 62.5 per cent for sensitive products such as cars.

In MERCOSUR, certain goods in special lists were exempted from the general tariff liberalisation (Annex I of the Agreement contain these lists). However, the items included in these lists were not rudimentary; 394 items for Argentina, 324 for Brazil, 439 for Paraguay and 960 for Uruguay. It has an Annex on Safeguards permitting the imposition of restrictions in case of a sudden surge of imports".

These examples constitute just a fraction of the total in RTAs. This last point brings us to our second proposition that the 'domestic interest groups' play a significant role in forming the shape of trade liberalisation in RTAs as they do in multilateral negotiations. 


\section{3- Domestic Dynamics of Protection and RTAs}

The level of trade protection and the structure of the trade policy tools are largely determined by the interests of various actors and their impact on the decisionmaking process ${ }^{43}$. It is not a coincidence that almost all RTAs contain exclusions and exceptions to liberalise trade. The groups seeking protection may be highly effective in inserting diverse means to protect trade in RTAs. This, finally, will make the RTA more restrictive with a lesser degree of trade creation. It is not so vital if we still end up with some trade creation anyway. However, the menacing side of the story begins when these groups display the same protectionist activities, this time at a broader level (i.e. regional rather than national) against the rest of the world. This is essential in order to understand whether an RTA is expansionary as Kemp and Wan theoretically argued.

Those who benefit from trade creation at the first stage when an RTA was formed may also gain from diverting trade away from more efficient producers outside the region. This, of course, will lead them to lobby against any potential expansion of the RTA. Bhagwati (1992) presents a good example of it from the case of the car industry in the EC by citing to the statement of Agnelli of Fiat: "The Single Market must first offer an advantage to European companies" (emphasis added). What is European is open to discussion. It is extremely hard to understand, from an economic point of view, why an ordinary car consumer in the UK should pay more to an Italian car producer rather than importing it cheaply from Japan just because the Italians are in the Community. A similar idea reflecting the same domestic concerns in the EC, is interest in Jacques Delors' statement: "The Single Market will be open, but it will not be given away" (Wolf, 1994; p. 48). In other words the EC as an RTA will be open to the products of non-members to the extent the domestic interests permit.

On the other hand, as Hoekman and Kostecki (1995) argue, protection-seeking lobbies have higher returns under RTAs than under multilateral deals as they have a 'bigger size of the protected market' at a regional level. Therefore, these protectionist groups at the national level may well establish region-wide organisations such as industry associations or private lobbying firms. Many industries in the EU have EUrolobby groups such as Eurofer for steel, CEFIC for chemicals or CCMAC for cars. These groups are better organised than the foreign producers as they have a greater stake in trade protection. Some even specialise in certain trade policy tools like CEFIC in antidumping or the textile association in Article 115 (Schuknecht, 1992). The in-

However, these actors not only include 'special interest groups' such as producer associations, consumer bodies elc. but also policy-makers (i.e. poiticians and bureaucrats) who may hold discretionary power. For the influence of policy-makers in trade policy matters see; Messerlin (1981), Finger, Hall and Nelson (1982) and Weck-Hannemann (1992). 
terest connection in RTAs may take place on many different levels. They can be regional or national, and the lobbies may try to influence them either simultaneously or consecutively. This provides the interest groups with different vehicles to represent themselves. If a local industry has difficulty in finding a protectionist policy tool at the national level it may take part in an EU-level lobbying group to demand it in Brussels. The same thing can be said for the consumers who benefit from trade liberalisation; but as Tumlir (1983) argues, their interests are harder to defend at the RTA level compared to the interests of producers ${ }^{44}$.

Furthermore, the domestic groups in a larger RTA may have a stronger position to influence the trade deals than if their countries entered into trade negotiations alone. As the bargaining power increases, their attention will be diverted from multilateral into regional initiatives, thereby bringing more discrimination into the world trade.

While considering the liberalisation effects of RTAs, it is equally necessary to be coutious about their likely damage to the multilateral process. The RTAs may facilitate the capture of liberalisation deals by interest groups having the aim of not reducing trade barriers, but to increase them. The denial of market access on grounds such as 'environmental' or 'social' matters seems to replace traditional trade barriers and to constitute a new protectionist surge in the near future. The RTAs should not serve as a 'Troian horse' allowing these 'new' barriers occupy the world trade agenda.

44 Tumlir, in his argument, apparently follows Olson's theory that the larger the groups are, the more difficult it is to provide for the collective good. As the consumers are larger and more diffused it is difficult for them to achieve a common goal (such as cheaper prices through trade liberalisation). 


\section{BIBLIOGRAPHY}

Aho, C.M. and S. Ostry (1960), "Trading Blocs: Pragmatic or Problematic Policy?" Economic Impact 1:11-17.

Akman M.S. (1990), "An Analysis of the Conformity of Regional Economic Integrations with Article XXIV of GATT", Marmara Joumal of European Studies 1(1-2): 225-239.

Anderson K. and R. Blackhurst (eds.) (1993), Regional Integration and the Global Trading System, New York: Harvester Wheatsheaf.

Baldwin R. (1987), "Multilateral Liberalisation" in The Unuguay Round: A Handbook of Multilateral Trade Negotiations, ed. by. M. Finger and A. Olechowski, Washington D.C.: The World Bank.

Balkır C. (1996), "Türkiye ve AT: 1980"lerde Dış Ticaret ve Doğrudan Dış Yatınmlar" in, Türkiye ve Avrupa llişkileried. by C. Balkır and A.M. Williams, Istanbul: Sarmal.

Bello, J.H. and A.F. Holmer (1993). "The North American Free Trade Agreement (NAFTA)", The international Lawyer, 27 (3): 589-602.

Benecke, D. (1991), "Eastem Europe-Stimulus for integration in Latin America" Aussenpolitik 42: $336-343$.

Bhagwati J. (1991), The World Trading System at Risk, New York: Harvester and Wheatsheaf.

Bhagwati J. (1992), "Regionalism versus Multilateralism" The World Economy 15(5): 535-555.

Bhagwati J. (1995), "The High Cost of Free Trade Areas", Financial Times (London, 31 May).

Bormann A. and G. Koopmann (1994), "Regionalisation and Regionalism in World Trade" Intereconomics 29(4): 163-170.

Condliffe J.B. (1951), The Commerce of Nations, London: G. Allen \& Unwin.

Curzon, G. (1965), Muttiateral Commercial Diplomacy, London: Michael Joseph.

Dam K. (1970), GATT: Law and International Economic Organization, Chicago: University of Chicago Press.

de Melo and A. Panagariya (eds.) (1992), New Dimensions in Regional Integration, Cambridge: Cambridge University Press.

Dobbs and M.S. Higgison (1995), Asia Pacific: Its Role in the New World Disorder, London: Mandarin. 
Dornbusch R. (1990), "Policy Options for Free Trade: The Case for Bilateralism" in, An American Trade Strategy: Options for the 1990s, ed. by Lawrence and Schultze, Washington: The Brookings Institution.

Dombusch R. (1993), "The Case for Bilateralism" in, Protectionism and World Welfare ed. by D. Salvatore, Cambridge: Cambridge University Press.

Echevarria V. (1997), "Dominican Republic's Exports Tumble" South, (London, May).

Emerson et. al. (1988), The Economics of 1992, Oxford: Oxford University Press.

EUROSTAT (1994), Extemal Trade Statistical Yearbook: 1958-1993, Luxembourg.

EUROSTAT (1996), External and Intra-European Union Trade: Monthly Statistics, 12, Luxembourg.

Fidler, S. (1997), "Economist's Report Stirs Controversy over Trade Pact's Performance", Financial Times (London, 4 February).

Finger, Hall and Nelson (1982), "The Political Economy of Administered Protection" in American Economic Review 72: 452-466.

Finlayson J.A. and M.W. Zacher (1982), "The GATT and the Regulation of Trade Barriers: Regime Dynamics and Functions" in, Intemational Regimes ed. by S. D. Krasner; thaca and London: Cornell University Press.

Frey B. (1991), "The Public Choice View of Intemational Political Economy", in Political Economy of Intemational Organizations, ed. by. R. Vaubel and T. D. Willett, Boulder. Westview.

Grinspun R. and M.A. Cameron (eds.) (1994), The Political Economy of North American Free Trade, New York: St. Martin's Press.

GATT (1994), Trade Policy Review: United States, Geneva.

Hillman A. (1989), The Political Economy of Protectionism, Chur: Hanwood.

Hindley B. and P. Messerlin (1993), "Guarantees of Market Access and Regionalism" in, Regional Integration and the Global Trading System ed. by Anderson and Blackhurst.

Hine R.C. (1992), "Regionalism and the Integration", Joumal of Common Market Studies 30 (2): 115-123.

Hoekman B. and M. Kostecki (1995), The Political Economy of the World Trading System, Oxford: Oxford University Press.

Hoekman B.M. and M.P. Leidy (1992), "Holes and Loopholes in Regional Trade Arrangements and The Multilateral Trading System" Aussenwirtschaft 47(3): 325-360. 
Huibauer G.C. and J.J. Schott (1993), NAFTA: An Assessment, Washington D.C.: Institute for International Economics.

Hufbauer G. C. and J.J. Schott (1994), Westem Hemisphere Economic Integration, WashingIon: Institute for International Economics.

Jackson J.H. (1969), World Trade and Law of GATT, Indianapolis: Bobbs Merrill.

Kahler M. (1993), "Multilateralism with Small and Large Numbers" in, Multilateralism Matters ed. by J.G. Ruggie, New York: Columbia University Press.

Kemp M. and H. Wan (1976), "Elementary Proposition Conceming the Formation of Custom Unions" Intemational Economic Review 6: 95-97.

Keohane R.O. (1984), After Hegemony: Cooperation and Discord in the World Political Economy, New Jersey: Princeton University Press.

Kodama Y. (1996), "Asia Pacific Region: APEC and ASEAN", Intemational Lawyer 30(2): 367-389.

Krueger A. (1990), "Free Trade is the Best Policy" in, An American Trade Strategy: Options for the 1990s, ed. by Lawrence and Schultze, Washington: The Brookings Institution.

Krugman P. (1991), "Is Bilateralism Bad?" in, International Trade and Trade Policy ed. by E. Helpman and A. Razin, Mass.: MIT Press.

Lal D. (1993), "Trade Blocs and Multilateral Free Trade" Joumal of Common Market Studies 31(3): 349-358.

Lawrence R.Z. (1990), "Discussion-to Dombusch's The Case for Bilateralism" in, An American Trade Strategy: Options for the 1990s, Washington D.C.: The Brookings Institution.

Lawrence R.Z. and C.L. Schultze (eds.) (1990), An American Trade Strategy: Options for the 1990s, Washington D.C.: The Brookings Institution.

Leidy M. and M. Hoekman (1993), "What to Expect from Regional and Multiateral Trade Negotiations: A Public Choice Perspective" in, Regional Integration and the Global Trading System ed. Anderson and Blackhurst.

Levy, B. (1994), "The EU and NAFTA: Two Regional Economic Blocs in a Complex Globalized and Interdependent Intermational Economy' Joumal of European Integration 17(2-3): 211-233.

Leutwiler, F. et. al. (1985), Trade Policies for a Better Future: Proposals for Action, Geneva: GATT Secretariat.

Lorenz D. (1991), "Regionalisation versus Regionalism - Problems of Change in the World Economy" in Intereconomics, 26 (1): 3-10. 
Lustig N., B.P. Bosworth and R.L. Lawrence (eds.) (1992), Assessing the Impact of North American Free Trade, Washington D.C.: The Brookings Institution.

Messerlin P. (1981), "The Political Economy of Protectionism: The Bureaucratic Case", Weltwirtschaftliches Archiv117 (469-496).

Messerlin P. (1992), "The Association Agreements between the EC and Central Europe: Trade Liberalization vs. Constitutional Failure?" in, Trade, Payments and Adjustment in Central and Eastem Europe ed. by J. Femming and J. Rollo, London: RllA.

Mansfield E. (1993), "Effects of Intemational Politics on Regionalism in Intemational Trade", in Regional Integration and the Global Trading System ed. by Anderson and Blackhurst.

McMillan J. (1993), "Does Regional Integration Foster Open Trade? Economic Theory and GATT's Article XXIV" in, Regional Integration and the Global Trading System ed. by Anderson and Blackhurst.

Mundell R.A. (1964), "Tariff Preferences and the Terms of Trade", in Intemational Economic Integration ed. by P. Robson, Penguin, 1972.

O'Keefe T.A. (1994), "An Analysis of the Mercosur Economic Integration Project from a Legal Perspective", Intemational Lawyer 28(2): 439-448.

Panagariya, A. (1994), "East Asia and the New Regionalism in World Trade", The World Economy 17(6):817-839.

Panagariya, A. (1995), "Nafta has Harmed Cause of Free Trade", Financial Times (London, 10 May).

Preusse, H.G. (1994), "Regional Integrations in the Nineties" Joumal of World Trade 28(4): 147-164.

Proff H.V. (1993), "The North American Trade Region" Intereconomics 28(6): 279-284.

Robson P. (1987), The Economics of International Integration, Third Ed., London: Allen \& Unwin.

Rollo J. and A. Smith (1993), "The Political Economy of Central European Trade with the EC: Why are So Sensitive?", Economic Policy 16: 140-181.

Sapir A. (1993), "Regional Integration and Trade" in European Economy: The EC as a World Trade Partner, Commission of the EC, No. 52.

Sazanami, Y. (1994), "GATT and Regional Arrangements Can Live Together", Dialogue Europe and Japan 1994 Workshop, by Canon Foundation and EUl in Florence. 
Schott J.J. (1991), "Trading Blocs and the World Trading System" the World Economy 14(1): 1 1.17.

Schuknecht L. (1992), Trade Protection in the European Community, Chur: Harwood.

Srinivasan T.N., J. Whalley and I. Wooton (1993), "Measuring the Effects of Regionalism on Trade and Welfare", in Regional Integration and the Global Trading System ed. by Anderson and Blackhurst.

Trebilcock M. and Howse (1995), The Regulation of Intermational Trade, London: Routledge.

Tsoukalis L. (1993), The New European Economy, Oxford: Oxford University Press.

Tumlir J. (1983), "Strong and Weak Elements in the Concept of European Integration" in Reflections on a Troubled World Economy ed. by F. Machlup et. al., London: Macmillan.

UNCTAD (1990), Handbook of International Trade and Development Statistics, 1990, Supplement, New York: United Nations.

Viner J. (1950), The Customs Union Issue, New York: Camegie Endowment for Intemational Peace.

Weck-Hannemann H. (1992), "Institutional Analysis of Protectionism" in European Integration in the World Economy, ed. by H.J. Vosgerau, Berlin: Springer-Verlag.

Wijkman P.M. (1994), "EFTA Countries" (Ch. 4) in, Reviving the European Union ed. by Henning et. al., Washington D.C., Institute for Intemational Economics.

Winters L.A. and Z.K. Wang (1994), Eastem Europe's Intemational Trade, Manchester and New York: Manchester University Press.

World Trade Organization (1995), Trade Policy Review: European Union, Geneva.

World Trade Organization (1996), Annual Report 1996, Vol. 1-2, Geneva.

Woll M. (1994), The Resistable Appeal of Fortress Europe, Rochesler Paper I, London: Centre for Policy Studies.

Yarbrough B.V. and R.M. Yarbrough (1992), Cooperation and Govemance in Intemational Trade, New Jersey: Princeton University Press.

Young, Soogil (1993), "East Asia as a Regional Force for Globalism", in Regional Integration and the Global Trading System ed. by Anderson and Blackhurst. 


\section{Annex. 1}

List of Regional Agreements Notified to the GATTNTO and Currently in Force" A. Agreements Notified Under Article XXIV

Date of Signature

1. EEC and EURATOM 25.03 .57

EC - Accession of Denmark, Ireland and UK

22.01 .72

EC - Greece Accession Agreement

28.05.79

EEC - Portugal and Spain Accessions

12.06 .85

EC - Austria, Finland, Sweden Accessions

25.06 .94

2. EFTA

04.01 .60

EFTA / FINEFTA - Iceland Accession

04.12 .69

3. Central American Common Market

13.12 .60

4. Arab Common Market

06.07 .62

5. EEC - Turkey Association Agreement of 1963

12.09 .63

EEC - Turkey Additional Protocol

23.11 .70

EC - Turkey Association Agreement of 1973

30.06 .73

EC - Turkey Customs Union

22.12 .95

6. EC - Association of certain non-European countries

29.09 .70 and ternitories (PTOM II)

7. EC - Malta Association Agreement

05.12 .70

8. EC - Switzerland / Liechtenstein Agreements

22.07 .72

9. EC - Iceland Agreements

22.07 .72

10. EC - Cyprus Association Agreement

19.12 .72

11. EC - Norway Agreements

14.05 .73

12. CARICOM

04.07 .73

13. EEC - Israel Agreement of 1975

11.05 .75

14. EEC - Algeria Agreements of 1976

26.04 .76

15. EEC - Morocco Agreements

27.04 .76

16. EEC - Tunisia Agreements of 1976

25.04 .76

17. Australia - Papua New Guinea Agreement (PATCRA)

06.11 .76

18. EEC - Egypt Interim Agreement of 1977

18.01.77

19. EEC - Jordan Interim Agreement of 1977

18.01 .77

20. EEC - Lebanon Interim Agreement of 1997

03.05 .77

21. EEC - Syria Interim Agreement of 1977

18.01 .77

22. Australia - New Zeland (ANZCERTA)

28.03 .83

23. Israel - United States Free Trade Area Agreement

22.04 .85

24. Canada - US Free Trade Agreement (CUSFTA)

02.01 .88

25. EC - Farce Islands Agreement

02.01 .91

26. EFTA - Turkey Agreement

10.12 .91 
27. EC - Hungary Interim Agreement of 1991

16.12 .91

28. EC - Poland Interim Agreement of 1991

16.12 .91

29. EFTA - Czech and Slovak Federal Republic Agreement

20.03.92

30. Estonia - Nonway Free Trade Agreement

15.07 .92

31. Latvia - Norway Free Trade Agreement

15.06 .92

32. Lithuania - Norway Free Trade Agreement

15.06 .92

33. EFTA - Israel Free Trade Agreement

17.09 .92

34. Czech Republic and Slovak Republic Customs Union

29.10 .92

35. Lithuania - Switzerland Free Trade Agreement

24.11 .92

36. EFTA - Poland Agreement

10.12 .92

37. EFTA - Romania Agreement

10.12 .92

38. NAFTA

17.12 .92

39. CEFTA

21.12.92

40. Estonia - Switzerland Free Trade Agreement

21.12 .92

41. Latvia - Switzerland Free Trade Agreement

22.12.92

42. Faroe Islands - Iceland Free Trade Agreement

43. Faroe Islands - Norway Free Trade Agreement

44. Faroe Islands - Switzerland Free Trade Agreement

45. EEC - Bulgaria Interim Agreement

08.03 .93

46. EFTA - Bulgaria Free Trade Agreement

29.03 .93

47. EFTA - Hungary Agreement

29.03 .93

48. EC - Czech Rep. Europe Agreement

04.10 .93

49. EC - Slovak Rep. Europe Agreement

04.10 .93

50. Slovak Republic - Slovenia Free Trade Agreement

22.12 .93

51. EEC - Romania Interim Agreement

01.02 .93

52. EC - Estonia Agreement

18.07 .94

53. EC - Latvia Agreement

18.07.94

54. EEC - Slovenia Cooperation Agreement

05.04 .93

55. Hungary - Slovenia Free Trade Agreement

06.04 .94

56. EC - Lithuania Agreement

18.07 .94

57. Czech Republic - Romania Free Trade Agreement

24.10.94

58. Slovak Republic - Romania Free Trade Agreement

59. Czech Republic - Slovenia Free Trade Agreement

60. EFTA - Slovenia Free Trade Agreement

13.06 .95

61. EFTA - Estonia Free Trade Agreement

07.12 .95

62. EFTA - Latvia Free Trade Agreement

07.12 .95

63. EFTA - Lithuania Free Trade Agreement

07.12 .95 


\section{B. Agreements Notified Under the Enabling Clause}

1. The Tripartite Agreement (Egypt, India, Yugoslavia)

2. Protocol relating to Trade Negotiations among Developing Countries

3. Bangkok Agreement

4. ASEAN Preferential Trading Arrangements 24.02 .77 Preferential Tariff Scheme for the ASEAN Free trade area (AFTA) 28.01 .92

5. South Pacific Regional Trade Cooperation Agreement (SPARTECA) 14.01 .80

6. Latin American Integration Association, "LAIA" 12.08 .80

7. Gulf Cooperation Council 08.06 .81

8. GSTP 13.04 .88

9. Laos - Thailand Trade Agreement 20.06 .91

10. MERCOSUR 26.03 .91

11. Preferential Tariffs among members of the Economic Cooperation Organization

12. Andean Pact

13. South Asian Preferential Trade Arrangement (SAPTA)

14. Common Market for Eastem and Southern Africa (COMESA) 